\title{
Predicting the yield and quality of winter wheat grown on calcareous chernozem in the lower Don Region
}

\author{
Olga Biryukova a,*, Ivan Elnikov b, Dmitry Bozhkov a, Tatiana Minkina ${ }^{\text {b }}$
}

a Southern Federal University, Rostov-on-Don, Russia

b Soil Institute named after V.V. Dokuchayev, Moscow, Russia

\begin{abstract}
\section{Article Info}

Received : 15.07.2014

Accepted : 19.02 .2015

Long-term studies have revealed a system of indicators for predicting the yield of winter wheat grown on a calcareous chernozem. It has been established that the prediction and integrated assessment of the yield and quality of grain should be performed with consideration for the balance of macro- and micronutrients in the grain and the above-ground biomass of plants. It has been shown that the contents of protein and gluten in winter wheat grain are mainly determined by the supply of plants with nitrogen and its balance with $\mathrm{Mn}, \mathrm{P}, \mathrm{Fe}, \mathrm{Zn}$, and K. Possibility of predicting the contents of macro- and micronutrients in wheat grain from the chemical composition of plants at the shooting stage has been revealed.
\end{abstract}

Keywords: Chernozem, winter wheat, plant chemical composition, protein, gluten, multinutrient diagnostics, plant nutrition balance.

(C) 2015 Federation of Eurasian Soil Science Societies. All rights reserved

\section{Introduction}

Wheat is the main culture of the global agriculture in terms of sown areas, croppage, and role in the history of the human civilization. It is without parallel in the adaptivity to different climatic conditions and cultivation ranges. Wheat is the leading agricultural crop of Russia. The production of winter wheat largely determines the economic parameters of the Southern and Northern Caucasian Federal districts of the Russian Federation. The yielding capacity of winter wheat is second only to that of rice. The mean yield of wheat is $30 \mathrm{dt} / \mathrm{ha}$ for the Russian Federation and 50-60 dt/ha for the advanced farms. The highest yield in Russia (103.6 dt/ha) was obtained in the Krasnodar krai; the world highest yield (170 dt/ha) was obtained in Canada. It was calculated that the global demand for wheat will increase with the growing population by $40 \%$ to 2020 (Su et al., 2011)

The Southern Federal district can offer high-quality grain on the world market, and the mean wheat yield should reach $55 \mathrm{dt} / \mathrm{ha}$ in 2020. This task can be achieved by an integrated approach involving the development and introduction of new cultivars with high yielding capacity and grain quality adapted to the regional weather conditions, as well as the perfection of wheat growing technology. Therefore, the prediction of grain yield and quality based on the revealed relationships between the properties of soils and the chemical composition of plants is a problem of current interest. The relationship between the nitrogen supply of cereal crops and the nitrogen content in the grain has been best studied by now. Numerous works deal with this issue (Gritsenko, 1974; Mineev and Pavlov, 1981; Ames et al., 2003; Mineev, 2005; Biryukova et al., 2005; Mohammed et al., 2013). However, the quality of grain also depends on the contents of other

\footnotetext{
${ }^{*}$ Corresponding author.

Southern Federal University, 194/1 Stachkist, Rostov-on-Don, 344090, Russia

Tel.: +78632433094

e-ISSN: 2147-4249
}

E-mail address: olga_alexan@mail.ru 
macro- and micronutrients, whose relationships with the chemical composition of plants at different stages of their development and the properties of soils are almost not understood.

The aim of this work was to develop an integrated system of indicators for predicting the yield and quality of winter wheat grain on calcareous chernozems in the Lower Don region.

\section{Material and Methods}

Long-term field studies were performed on the production plantations of winter wheat in the Rostov oblast. For the formation of the experimental data base, soil and plant samples were simultaneously taken from microplots according to the procedure described in Methodological Recommendations on the Regulation of Macro- and Micronutrient Ratios in Plants According to the ISOD System (Anonymous, 1989).

The analyses of soil samples were performed by the standard methods (Mineeva, 2001). In the plant samples, the following macro- and micronutrients were determined by the X-ray fluorescence method (Anonymous, 1983): P, K, Cl, S, Si, Fe, Ni, Sr, Mn, Zn, Cu, Br, Cr, $\mathrm{Al}, \mathrm{Ca}$, and $\mathrm{Mg}$. Nitrogen in plants, gluten in grain, and grain hardness were determined according to the corresponding state standards (GOST 1084691; GOST 10987-76; GOST 13586.1-68).

The developed data base was used for studying the response of plants to the intrafield heterogeneity of growing conditions by statistical methods. For the more complete description of this response and the study of the balance of changes in different parameters, the equations of the integrated system of on-line diagnostics (ISOD) were used. The results of the diagnostics of plant supply with numerous macro- and micronutrients are recorded using these equations (El'nikov, 2002).

\section{Results and Discussion}

Long-term data showed that the arable calcareous chernozems are characterized by the high spatial heterogeneity of agrochemical parameters and winter wheat productivity (Table 1).

Table 1. Spatial variation of the calcareous chernozem fertility parameters and the winter wheat productivity in the production plantations

\begin{tabular}{|c|c|c|c|c|c|}
\hline \multicolumn{2}{|c|}{$\begin{array}{l}\text { Agrochemical parameters of calcareous } \\
\text { chernozem }\end{array}$} & \multicolumn{2}{|c|}{$\begin{array}{l}\text { Contents and ratios of chemical } \\
\text { elements in the above-ground } \\
\text { biomass of winter wheat }\end{array}$} & \multicolumn{2}{|c|}{$\begin{array}{l}\text { Parameters of plant response to } \\
\text { the growing conditions }\end{array}$} \\
\hline Parameter & $\begin{array}{l}\text { Minimum- } \\
\text { maximum }\end{array}$ & Parameter & $\begin{array}{l}\text { Minimum- } \\
\text { maximum }\end{array}$ & Parameter & Minimum-maximum \\
\hline G & $2,7-4,4$ & $\mathrm{~N} / \mathrm{Si}$ & $0,7-8,0$ & U & $20-58$ \\
\hline Ps & $22,0-58,0$ & $\mathrm{P}$ & $0,2-1,2$ & $\mathrm{H} 1$ & $45,0-90,0$ \\
\hline Ks & $240,0-460,0$ & $\mathrm{~K}$ & $1,0-4,0$ & M1 & $10,0-30,0$ \\
\hline Cas & $28,0-35,0$ & $\mathrm{~N} / \mathrm{P}$ & $5,0-15,0$ & M2 & $2,0-6,0$ \\
\hline Mgs & $4,0-6,5$ & $\mathrm{~N} / \mathrm{K}$ & $0,3-3,6$ & Bel & $11,0-16,0$ \\
\hline $\mathrm{pH}$ & $7,0-7,8$ & $\mathrm{~K} / \mathrm{P}$ & $2,0-16,0$ & $\mathrm{Kl}$ & $22,0-35,0$ \\
\hline Ks/Cas & $0,7-2,2$ & $\mathrm{Fe} / \mathrm{Zn}$ & $4,0-56,0$ & St & $45,0-72,0$ \\
\hline Cas/Mgs & $5,0-8,4$ & $\mathrm{Sr}$ & $5,0-54,0$ & & \\
\hline Cas+Mgs & $32,0-40,0$ & $\mathrm{Mn}$ & $40,0-128,0$ & & \\
\hline $\mathrm{Ps} / \mathrm{G}$ & $0,5-1,7$ & $\mathrm{Zn}$ & $5,0-31,0$ & & \\
\hline Ks/Cas & $0,7-2,2$ & $\mathrm{Ca}$ & $0,14-0,6$ & & \\
\hline Ks/Mgs & $4,0-15,0$ & $\mathrm{Si}$ & $0,4-1,8$ & & \\
\hline Ps/Mgs & $0,4-1,4$ & $\mathrm{~N}$ & $1,2-3,4$ & & \\
\hline
\end{tabular}

Note (here and below): $U$ is the yield of winter wheat grain, $\mathrm{dt} / \mathrm{ha}$; $\mathrm{H} 1$ is the plant height at the shooting stage, $\mathrm{cm}$; M1, M2 are the green mass of the plant at the shooting stage and the dry mass of the plant at the full ripeness stage, respectively, g; Prot, Glut, Hard are protein, gluten, and grain hardness, respectively, \%; the contents of N, P, K, Si, and $\mathrm{Ca}$ are given in \%; the contents of $\mathrm{Mn}, \mathrm{Zn}, \mathrm{Fe}$, and $\mathrm{Sr}$ are given in $\mathrm{mg} / \mathrm{kg}$; N/P, N/K, K/P, Fe/Zn, N/Si are the ratios of the elements. Agrochemical parameters in the plow layer of soil: $G$ is the content of humus, \%; Ks and Ps denote exchangeable potassium $\left(\mathrm{K}_{2} \mathrm{O}\right)$ and available phosphorus $\left(\mathrm{P}_{2} \mathrm{O}_{5}\right)$, respectively, $\mathrm{mg} / \mathrm{kg}$ soil; Cas, Mgs are exchangeable calcium $\left(\mathrm{Ca}^{2+}\right)$ and magnesium $\left(\mathrm{Mg}^{2+}\right), \mathrm{mmol}(+) / 100 \mathrm{~g}$ soil; Ks/Cas, Ps/G, Cas/Mgs, Ks/Cas+Mgs are the ratios between the above soil properties.

It should be emphasized that the spatial heterogeneity is typical not only for separate soil parameters, but also for their balance (or ratios). Presently, the balance of soil properties is not considered at the assessment of their fertility. Available data indicate that the ratios of some physico-chemical properties can be leading 
integrated indicators of soil suitability for growing separate crops, especially on the soils with pronounced microheterogeneity (El'nikov and Savvinova, 2006). It was revealed that the ratios between the essential soil properties in the plow layer have wider variation amplitudes than their absolute values. So, the maximum contents of exchangeable potassium and calcium in the studied chernozem exceed their minimum contents by 1.9 and 1.3 times, respectively, while the extreme ratios of these parameters (Ks/Cas) differs by 3.1 times. This example indicates that the ratio of the parameters more adequately reflects the microheterogeneity of soil than their separate values. The high spatial variation is also typical for the elemental composition of the above-ground wheat biomass at the shooting stage. It raises the question about the degree of agreement between the variation of wheat productivity parameters and the chemical composition of its above-ground biomass, on one side, and the above parameters, on the other side. To answer this question, the multiple regression analysis of the long-term data base was performed, which revealed clear correlations between the yield of wheat grain and some soil properties and their pair ratios (Figure 1 and 2).

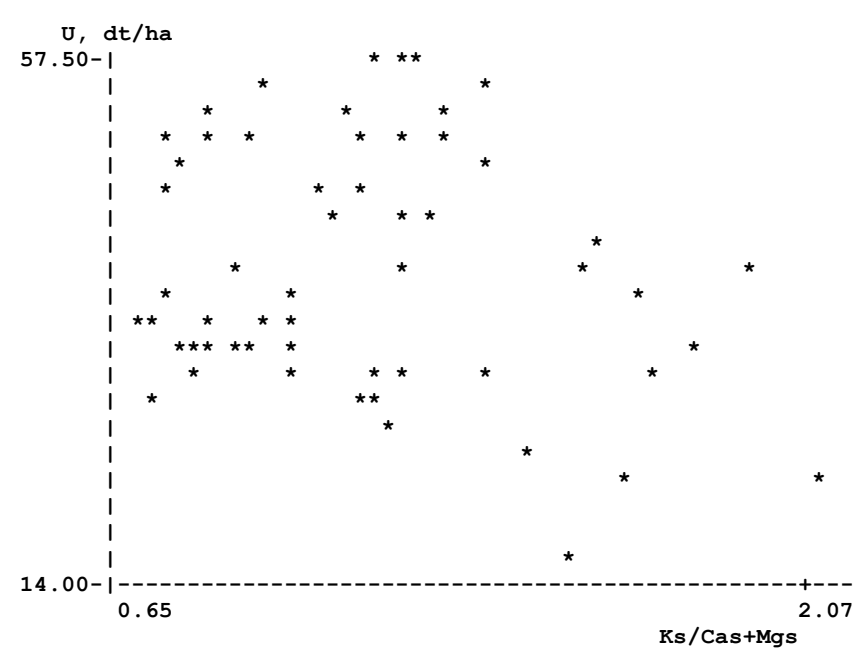

Figure 1. Yield of winter wheat grain as a function of the ratio of exchangeable potassium to total exchangeable bases (Ks/Cas+Mgs) in the soil.

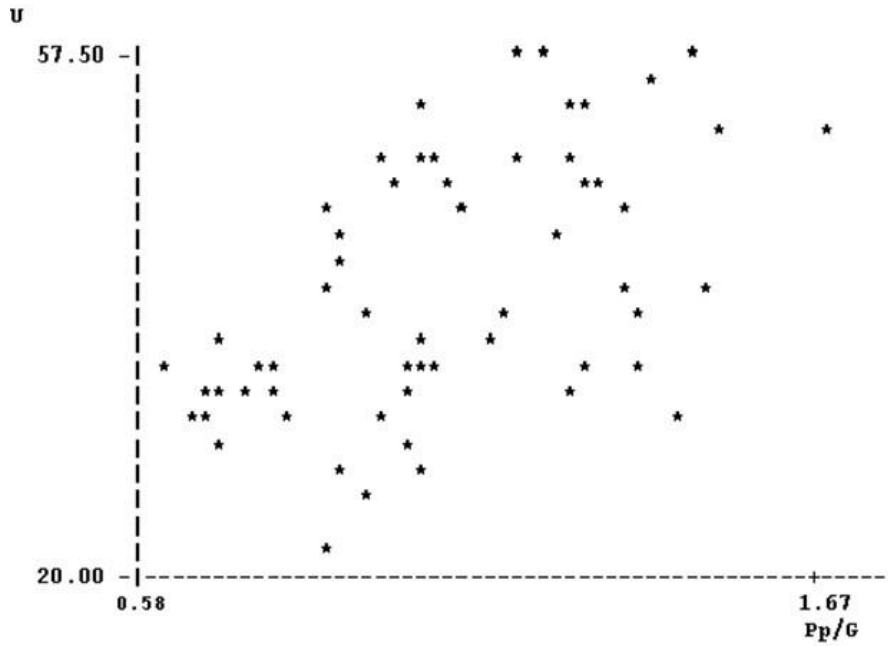

Figure 2. Yield of winter wheat grain (U, dt/ha) as a function of the ratio of available phosphorus to humus $(\mathrm{Ps} / \mathrm{G})$ in the plow soil layer.

Highly reliable and stable correlations were observed for the yield of winter wheat grain only at the simultaneous consideration of numerous parameters characterizing the state of plants and soil: the contents of $\mathrm{N}, \mathrm{Si}, \mathrm{P}, \mathrm{K}(\%), \mathrm{Fe}, \mathrm{Ni}, \mathrm{Cu}, \mathrm{Mn}, \mathrm{Sr}$, and $\mathrm{Zn}(\mathrm{mg} / \mathrm{kg})$; the $\mathrm{Fe} / \mathrm{Mn}, \mathrm{N} / \mathrm{K}, \mathrm{K} / \mathrm{P}$ ratios in the above-ground plant biomass at the shooting stage; the contents of humus (\%), available phosphorus, and exchangeable potassium (mg/kg soil); and the contents of exchangeable calcium and total exchangeable bases $(\mathrm{mmol}(+) / 100 \mathrm{~g})$ in the plow player of soil.

We define these parameters as a system of indicators directly or indirectly chaarcterizing the conditions of wheat growing. The high information value of the above parameters is clear, because they are more closely related to the agrochemical features of calcareous chernozem. The new is the inclusion of the $\mathrm{Sr}$ content in the above-ground wheat biomass at the shooting stage into the system of indicators. The content of Sr in plants positively correlates with the content of calcium (Figure 3).

This can explain in part the high diagnostic value of the $\mathrm{Sr}$ content in the above-ground biomass of plants on the studied soils as an indicator of the wheat growing conditions. From our data, the contents of $\mathrm{Ca}$ and $\mathrm{Sr}$ and their ratio in the aboveground plant biomass (at the shooting stage) also affects the accumulation of phosphorus in wheat grain.

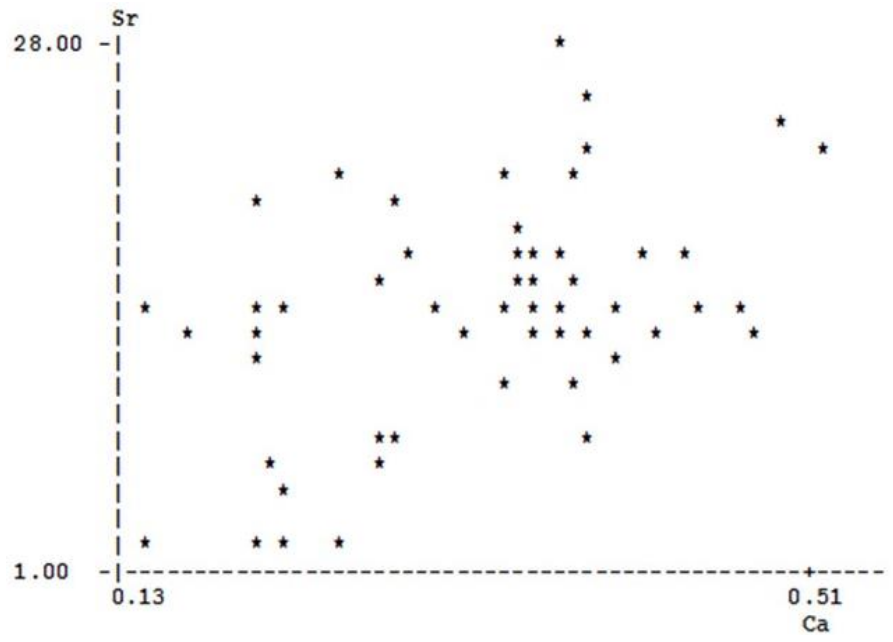

Figure 3. Changes in the contents of strontium (Sr, mg/kg) and calcium $(\mathrm{Ca}, \%)$ in the above-ground wheat biomass at the shooting stage. 
The efficiency of using the above parameters as indicators of wheat growth conditions was confirmed by multiple regression analysis. The model best describing the agrochemical features of calcareous chernozem and most accurately predicting the yield of winter wheat grain included 17 indicator parameters (Model 1):

$\mathrm{U}_{\mathrm{t}}=-132.00+5.65 \mathrm{~N}-9.76 \mathrm{Si}+13.65 \mathrm{P}-12.60 \mathrm{~K}+0.20 \mathrm{Mn}-0.05 \mathrm{Fe}-0.47 \mathrm{Ni}+0.16 \mathrm{Sr}+0.56 \mathrm{Cu}+$

$3.74 \mathrm{Ps}-2.16 \mathrm{Ks}+75.80 \mathrm{Ks} / \mathrm{Cas}+3.24 \mathrm{Cas} / \mathrm{Mgs}+3.40$ (Cas $+\mathrm{Mgs})+3.75 \mathrm{Fe} / \mathrm{Mn}-8.40 \mathrm{~N} / \mathrm{K}+1.64 \mathrm{~K} / \mathrm{P}$

$\mathrm{F}=2.1, \mathrm{R}^{2}=0.70$.

A simpler model (model 2) was developed for the preliminary express prediction:

$\mathrm{U}_{\mathrm{t}}=40.4+9.1 \mathrm{~N}-7.9 \mathrm{Si}-7.9 \mathrm{~K}+4.3 \mathrm{Ps}-11.1 \mathrm{~N} / \mathrm{K}$

$\mathrm{F}=2.03, \mathrm{R}^{2}=0.55$.

The agreement between the predicted (from model 1) and the factual yields is shown in Figure 4. Of special interest is the study of changes in the crop yield predicted using the integrated system of indicators for different gradations of the agrochemical parameters of soil (Table 2).

Table 2. Wheat productivity predicted from the mathematical model as a function of soil agrochemical parameters and their ratios in production plantations

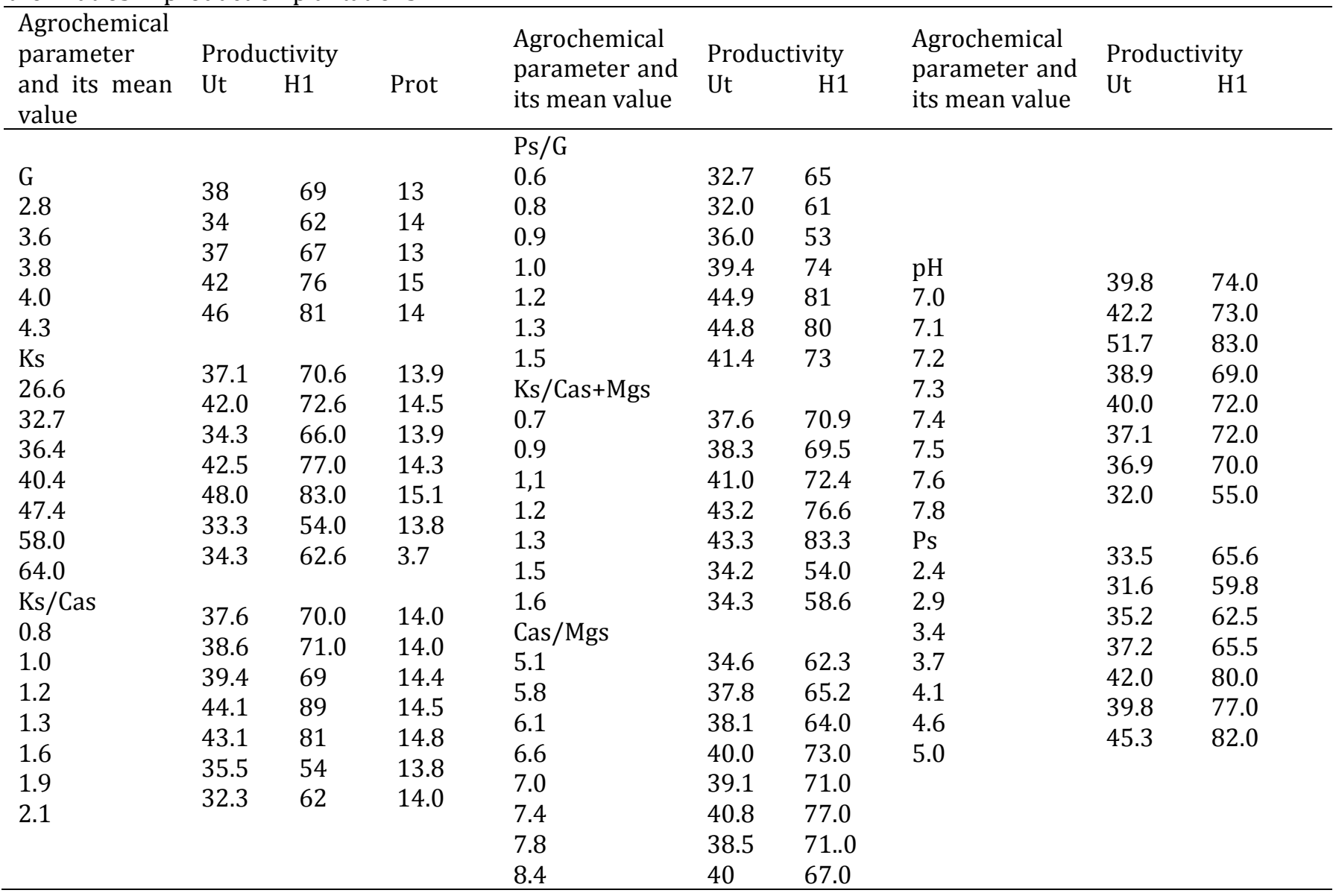

Note: Ut is the yield of winter wheat grain predicted from model $1, \mathrm{dt} / \mathrm{ha}$.

The change of wheat productivity among the gradations of soil properties and their ratios is found to be not chaotic and can be described by a nonlinear curve. This allows defining the permissible and impermissible changes in the soil properties for winter wheat. We define the impermissible changes of soil properties as the changes corresponding to a decrease of wheat grain yield by $15 \%$ and more compared to the maximum value. An especially abrupt decrease of the winter wheat yield is observed on the soils with $\mathrm{pH}>7.4$. The soils with the narrow ratios between available phosphorus and humus $(<0.8)$ and the ratios between exchangeable potassium and adsorbed calcium Ks/Cas higher than 1.9 or lower than 1.0 are also unfavorable for wheat growing. 
In each group of soil parameters, the decrease of the yield is due to the effect of the studied soil property on the nutrition of plants. This disturbance can result from the changes in the content of one or several chemical elements in plants, e.g., the N/K ratio (Figure 5).

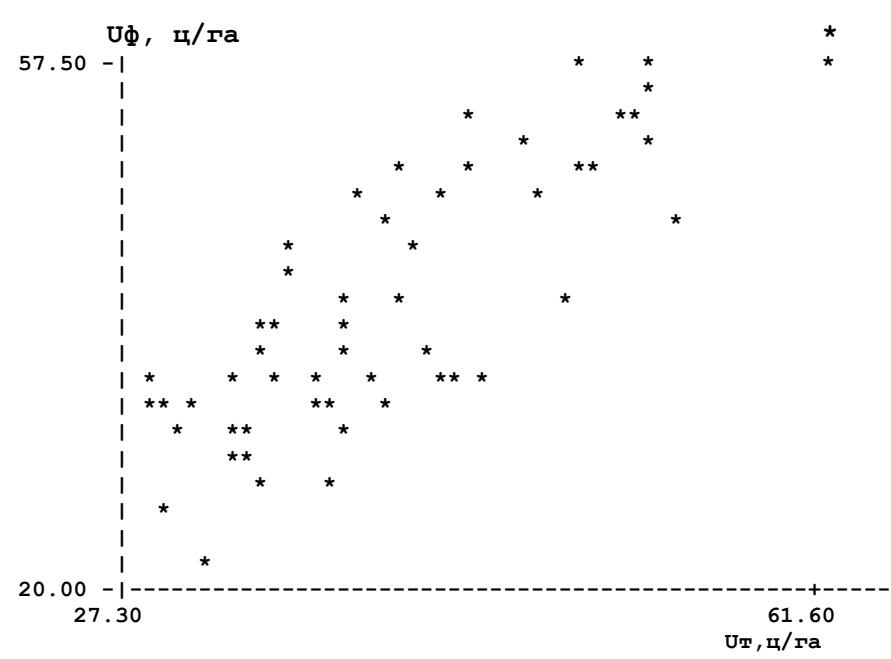

Figure 4. Correlation between the factual (Uf) and predicted (Ut) yields of winter wheat grain.

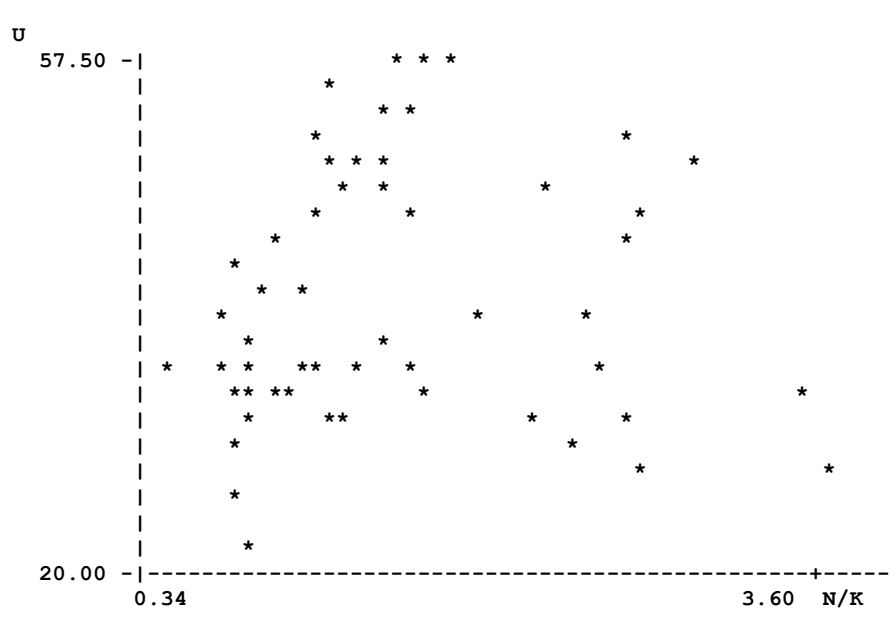

Figure 5. Yield of winter wheat grain $(\mathrm{U}, \mathrm{dt} / \mathrm{ha})$ as a function of nitrogen/potassium $(\mathrm{N} / \mathrm{K})$ ratio in the aboveground plant biomass at the shooting stage.

A clear correlation was revealed between the content of available phosphorus in the soil and the ratios of some elements to $\mathrm{Fe}$ in plants (Table 3).

Table 3. Effect of the content of available phosphorus in the soil on the ratios of iron to other elements in the aboveground wheat biomass at the shooting stage

\begin{tabular}{|c|c|c|c|}
\hline $\begin{array}{l}\text { Mean content of available phosphorus } \\
\left(\mathrm{P}_{2} \mathrm{O}_{5}, \mathrm{mg} / \mathrm{kg}\right)\end{array}$ & $\begin{array}{l}\text { Ratios } \\
\text { Fe/Mn }\end{array}$ & & $\mathrm{Fe} / \mathrm{Mn}$ \\
\hline 24,0 & 3.5 & 22.5 & 23.9 \\
\hline 30,0 & 2.0 & 17.4 & 52.2 \\
\hline 36,0 & 4.2 & 22.8 & 45.0 \\
\hline 40,0 & 3.5 & 22.0 & 26.6 \\
\hline 46,0 & 3.0 & 14.7 & 14.5 \\
\hline 50,0 & 2.8 & 15.0 & 16.5 \\
\hline 55,0 & 2.7 & 14.0 & 11.3 \\
\hline
\end{tabular}

It is especially important to take this relationship into consideration for calcareous chernozems at the agroecological assessment of lands, because the availability of iron to plants is low at the increased phosphorus content under alkaline conditions. According to the results of studies, the deficit of iron is more frequently due to the disturbance of its balance with other elements, including phosphorus. The mean values of indicator parameters at which a winter wheat grain yield of $50 \mathrm{dt} /$ ha is predicted are given in Table 4 . This yield can be considered maximum at the growing of wheat on the unirrigated soils in the southern Russia. Therefore, these parameters can be considered optimum and used as criteria for the integrated assessment of the optimality of soil conditions. The studies showed that the content of protein in winter wheat grain primarily depends on the deficit of nitrogen and its balance with $\mathrm{Fe}, \mathrm{P}$, and Mn (Figure 6).

The antagonism of these elements with $\mathrm{N}$ in plants can result in the deficit of $\mathrm{Mn}, \mathrm{P}$, and Fe. This can decrease the content of protein in grain. Although the deficit of Mn does not hinder the synthesis of amino acids, its lack hampers their use for the synthesis of proteins (Zhiznevskaya, 1972). Under conditions of Mn deficit, the photosynthesis is disturbed and gives insufficient contents of carbohydrates, which are considered among the key factors limiting the growth of roots (Bityutskii, 1999). The data about the effect of the agrochemical properties of soils and the biometric parameters and chemical composition of plants at the shooting stage on the content of gluten were also analyzed (El'nikov and Biryukova, 2011). This allowed revealing the system of indicators for the early prognosis of the essential quality parameters of winter wheat 
grain. The system of indicators for predicting the content of protein in the grain of winter wheat grown on calcareous chernozem includes 19 indicators.

Table 4. Assessment criteria of the growing conditions of winter wheat on calcareous chernozem

\begin{tabular}{llll}
\hline \multicolumn{2}{c}{ Chemical elements and their ratios in plants } & Physico-chemical properties of soil and biometric parameters of plants \\
\hline & $\%:$ & $\mathrm{G}$ & 4.3 \\
$\mathrm{~N}$ & 3.0 & $\mathrm{Ps}\left(\mathrm{P}_{2} \mathrm{O}_{5}\right)$ & 4.0 \\
$\mathrm{Si}$ & 0.8 & $\mathrm{Ks}\left(\mathrm{K}_{2} \mathrm{O}\right)$ & 40.0 \\
$\mathrm{P}$ & 0.3 & $\mathrm{Ks} / \mathrm{Cas}$ & 1.3 \\
$\mathrm{~K}$ & 2.0 & $\mathrm{Cas} / \mathrm{Mgs}$ & 7.1 \\
& $\mathrm{Mg} / \mathrm{kg} \mathrm{d.m.:}$ & $\mathrm{Cas}+\mathrm{Mgs}$ & 36.0 \\
$\mathrm{Mn}$ & 70.0 & $\mathrm{pH}$ & \\
$\mathrm{Fe}$ & 180.0 & & \\
$\mathrm{Ni}$ & 2.0 & plants height, cm & \\
$\mathrm{Sr}$ & 15.0 & & \\
$\mathrm{Cu}$ & 7.0 & & \\
& Ratios & & \\
$\mathrm{Fe} / \mathrm{Mn}$ & 2.4 & green mass of one plant, $\mathrm{g}$ & \\
$\mathrm{N} / \mathrm{K}$ & 1.2 & & \\
$\mathrm{~K} / \mathrm{P}$ & 8.3 & & \\
\hline
\end{tabular}

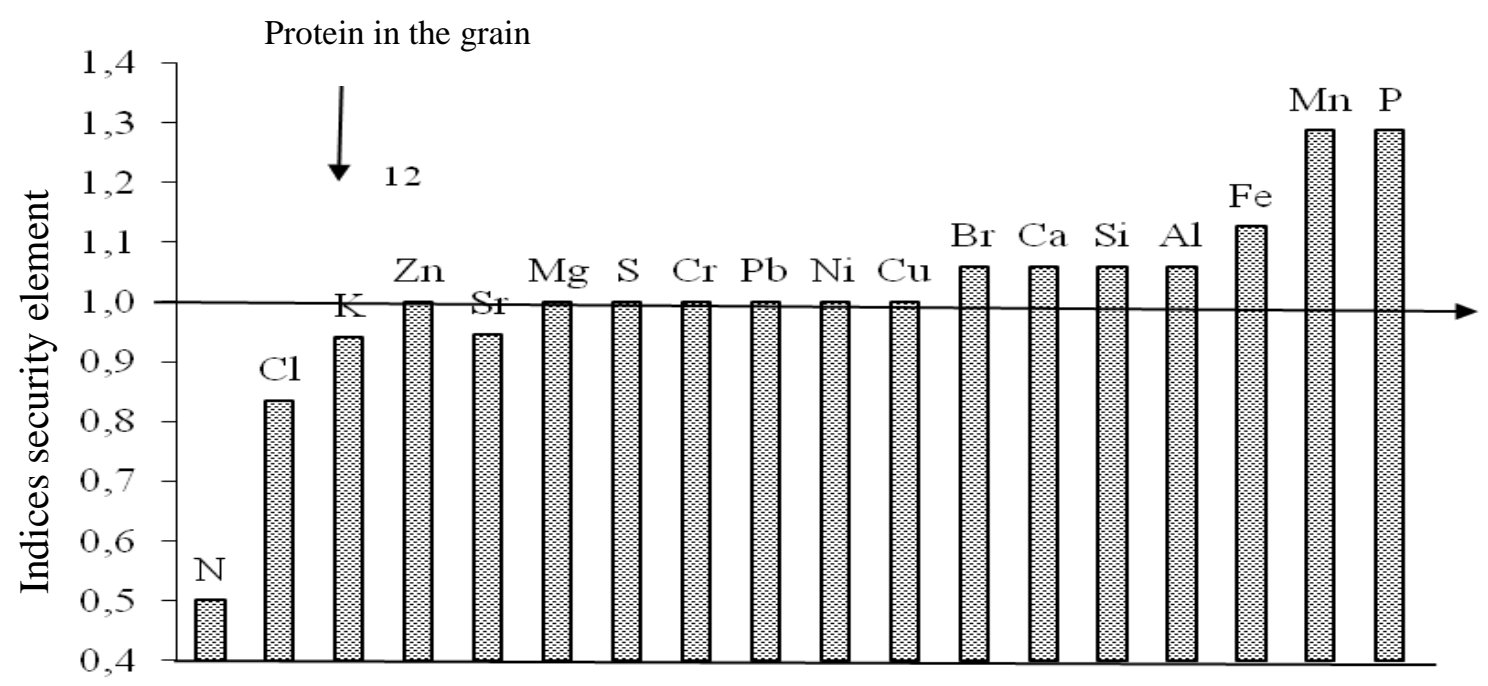

Figure 6. Changes in the content of protein in winter wheat grain depending on the indices of macro- and micronutrient supply.

In the soil, these are the contents of available phosphorus and exchangeable potassium and their ratio, as well as the phosphorus to humus ratio. The indicator elements in plants are N, Cl, K, P, and $\mathrm{Ca}(\%) ; \mathrm{Mn}, \mathrm{Fe}$, and $\mathrm{Zn}(\mathrm{mg} / \mathrm{kg})$; the N/P, N/K, Mn/N, Fe/Zn, and N/Ca ratios; and the weight of one plant (g). The early monitoring of wheat plantations for the content of protein can be performed using the following model:

Prot, $\%=12,7-0,31 \mathrm{Ps}+0,06 \mathrm{Ks}+1,55 \mathrm{Ps} / \mathrm{G}+0,54 \mathrm{~N}-0,73 \mathrm{~N} / \mathrm{K}-4,2 \mathrm{Cl}-0,012 \mathrm{Mn}-0,74 \mathrm{P}+$

$0,011 \mathrm{Fe} / \mathrm{Zn}$

$\mathrm{F}=3.5, \mathrm{R}^{2}=0.8$

This model best reflects the agrochemical features of calcareous chernozem. In a year with favorable climatic conditions, the content of protein in the grain of winter wheat grown on the soil highly supplied with available phosphorus can be predicted from only two parameters:

Prot, $\%=11,3+0,06 \mathrm{Ks}+0,46 \mathrm{~N}$

$\mathrm{F}=3.4, \mathrm{R}^{2}=0.7$

\section{Conclusion}

Long-term studies showed that calcareous chernozem is characterized by the high variation of agrochemical parameters (humus, available phosphorus, exchangeable potassium, $\mathrm{pH}$, etc.). The variation of these 
parameters enhances the imbalance of plant nutrition with many macro- and micronutrients affecting the yield, quality, and environmental safety of crops. It was found that winter wheat strongly responses to the variation of nutrition quality. Reliable correlations were found between the crop yield and the contents of chemical elements and their ratios, which allow predicting the productivity of plants at the early development stage and assessing the fertility of soils on the basis of the environmentally significant ratios of chemical elements $(\mathrm{P} / \mathrm{Ca}, \mathrm{Fe} / \mathrm{Mn}, \mathrm{Sr} / \mathrm{Ca}$, etc.). The following parameters are efficient indicators of the growing conditions of winter wheat on calcareous chernozem: the contents N, P, K, Fe, Zn, and Ca and their ratios in the above-ground wheat biomass at the shooting stage; the contents of humus and available phosphorus and their ratio; and the content of exchangeable potassium and its ratios to exchangeable calcium and total exchangeable bases. It was shown that the prediction and integrated assessment of the grain quality of wheat grown on calcareous chernozem should be performed with consideration for the balance of macro- and micronutrients in wheat grain, the above-ground plant biomass at the shooting stage, and the ratios of soil properties. It was found that the contents of protein and gluten in the grain of winter wheat grown on calcareous chernozem largely depend on the balance of $\mathrm{N}$ with $\mathrm{Mn}, \mathrm{P}, \mathrm{Fe}, \mathrm{Zn}$, and $\mathrm{K}$ in plants at the shooting stage and the ratio between exchangeable potassium and humus in the soil. The use of the integrated diagnostic system of plant nutrition expands opportunities for predicting the yield and grain quality of winter wheat grown on calcareous chernozem.

\section{Acknowledgements}

This research was supported by Russian Ministry of Education and Science, project no. № 5.885.2014/K

\section{References}

Ames, N.P., Clarke, J.M., Dexter, J.E., Woods, S.M., Selles, F., Marchylo, B., 2003. Effects of nitrogen fertilizer on protein quantity and gluten strength parameters in wheat cultivars of variable gluten strength. Cereal Chemistry 80(2): 203-211.

Anonymous, 1983. Energy dispersive X-ray fluorescence analysis of plants: Methodological recommendations. Pochv. Inst. im. Dokuchaeva, Moscow (in Russian).

Anonymous, 1989. Methodological recommendations on the regulation of macro- and micronutrient ratios in plants according to the ISOD system. RASKHN, Moscow (in Russian).

Biryukova, O.A., Lanina, M.F., Lanin, I.I., 2005. Diagnostics of the grain quality of winter wheat grown on calcareous ordinary chernozem. In: Collection of articles of the Faculty of Biology and Soil Science, Rostov State University, Rostizdat, Rostov-on-Don, pp 25-29.

Bityutskii, N.P., 1999. Microelements and the plant, SPbU, St. Petersburg (in Russian).

El'nikov, I.I., 2002. Balance of the mineral nutrition of plants on different soils. In: Soils of the Moscow oblast and their use, Moscow, 1: 439-481.

El'nikov, I.I., Biryukova, O.A., 2011. Diagnostics of winter wheat grain quality on calcareous chernozem. Probl Agrokhim Ecol. 4: 20-24.

El'nikov, I.I., Savvinova, E.N., 2006. Effective fertility of agrosoddy-podzolic soils after the long-term aftereffect of mineral and organic fertilizers. In: Problems of soil science: Transactions of the Dokuchaev Soil Science Institute, Moscow, pp 258-280 (in Russian).

GOST 10846-91 Grain and products of its processing. Method for determination of protein.

GOST 10987-76 Grain. Methods of determination of hardness.

GOST 13586.1-68 Grain. Methods of determination of the quantity and quality of gluten in wheat.

Gritsenko, A.A. 1974. Effect of fertilizers and weather on the content of protein in the Bezostaya 1 winter wheat grain. Agricultural Chemistry 10: 50-54.

Mineev, V.G., 2005. Selected works: Collection of articles in 2 parts, MGU, Moscow (in Russian).

Mineev, V.G., Pavlov, A.N., 1981. Agrochemical fundamentals of improving the wheat grain quality, Kolos, Moscow (in Russian).

Mineeva, V.G., 2001. Workshop on Agricultural Chemistry: Textbook. Moscow State University, Moscow.

Mohammed, Y.A., Kelly, J., Chim, B.K., Rutto, E., Waldschmidt, K., Mullock, J., Torres, G., Desta, K.G., Raun, W., 2013, Nitrogen fertilizer management for improved grain quality and yield in winter wheat in Oklahoma. Journal of Plant Nutrition 36, 749-761.

Su, Z., Hao, C., Wang, L., Dong, Y., Zhang, X., 2011. Identification and development of a functional marker of TaGW2 associated with grain weight in bread wheat (Triticumaesttvum L.). Theoretical and Applied Genetics 122: 211223.

Zhiznevskaya, G.Ya., 1972. Copper, molybdenum, and iron in the nitrogen exchange of leguminous plants, Nauka, Moscow (in Russian). 